\title{
Inventory of some Tulipa species from Uzbekistan using DNA barcoding
}

\author{
Elena V. Nikitina ${ }^{1 *}$, Farkhod I. Karimov ${ }^{1}$, Natalja V. Savina ${ }^{2}$, Svetlana V. Kubrak ${ }^{2}$, and \\ Aleksandr V. Kilchevsky ${ }^{2}$ \\ ${ }^{1}$ Institute of Botany, Academy of Sciences of Uzbekistan, 100125 Tashkent, Uzbekistan \\ ${ }^{2}$ Institute of Genetics and Cytology of the National Academy of Science of Belarus, 220072 Minsk, \\ Belarus
}

\begin{abstract}
Climate fluctuations in the Quaternary period in significantly influenced the evolution and distribution of plants, which caused to a serious genetic effects and speciation activity [1]. Thus, Central Asia is distinguished by a wide variety of flora, including 9520 species, while $20 \%$ are endemics [2]. Great phenotypic diversity of the wild flora in Uzbekistan, numbering about 4400 species of vascular plants is determined by the peculiar climatic conditions, a variety of zoning, altitudinal zones [3]. At the same time, being one of the centers of early diversification of monocotyledonous geophytes, taxonomically complex representatives of this group are not sufficiently involved in phylogenetic studies. This study is a pilot study of the flora of Uzbekistan using DNA barcoding method, that based on sequencing of phylogenetically significant sequences. Four plastid (rbcL, psbA-trnH, matK, trnL-F) and one nuclear (ITS) markers were used for species identification of the genus Tulipa. The results of molecular phylogenetic analysis for 15 species of Tulipa (Liliaceae) using the marker sequence encoding ITS fragment are presented. The successful usefulness of DNA technology for genetic inventory has been demonstrated.
\end{abstract}

\section{Introduction}

The Liliaceae family includes 15 genera and more than 600 species [4]. In the flora of Uzbekistan, the family is represented by 7 genera: Gagea, Tulipa, Lloydia, Korolkowia, Rhinopetalum, Fritillaria, Petilium, including approximately 250 species.

Species of the genus Tulipa L. (Liliaceae), occupying a leading position in the flora of Uzbekistan, were used as model objects in this molecular phylogenetic analysis. It is one of the largest genus of Liliaceae family, it includes about 100 species distributed in the southern and eastern Europe, North Africa, the Middle East, Central Asia and China [5]. In recent years, the classification has changed dramatically, based on the classical and modern molecular phylogenetic studies [4-6]. This study allows to express an opinion about the taxonomic position selected objects. Thus, in previously published works on taxonomic studies of the genus Tulipa, the species number is various: from 76 [6], 87 species [5] to up

\footnotetext{
* Corresponding author: elenanikita2013@ rambler.ru
} 
114 species [7]. Currently 34 species of Tulipa have been recorded in Uzbekistan, united into six sections (Tulipanum, Kolpakovskiana, Lanatae, Vinistriatae, Spiranthera, Biflores) [8], 19 of them are listed in the Red Book of Uzbekistan (2019) [9]. The species investigated in this study ( 9 taxa) are representatives of five sections.

\section{Results and discussion}

The purpose of this study is an inventory of species diversity using the DNA barcoding method, also creation of DNA barcodes reference library of rare and endangered Tulipa species. The total DNA was isolated from fresh and herbarium plant materials using commercial set GeneJET Plant Genomic DNA Purification Kit (Thermo Scientific, USA) according to the manufacturer's protocol, with some modifications for herbarium specimens. Both nuclear and chloroplast DNA markers were amplified with a C1000 Touch Thermal Cycler (BioRad, USA) using specific primers: rbcL (rbcLaF 5'atgtcaccacaaacagagactaaagc-3', rbcLaR 5'-gtaaaatcaagtccaccgcg - 3'); matK (matK-xF 5'taatttacgatcaattcattc-3', MALPR1 5'-gttctagcacaagaaagtcg-3'); psbA-trnH ( $p s b A 3 \_F$ 5'gttatgcatgaacgtaatgctc-3', trnHf_05 5'- cgcgcatggtggattcacaatcc-3'); trnL-F (trnL-F_F 5'cgaaatcggtagacgctacg -3'; trnL-F_R 5'- atttgaactggtgacacgag- 3'), ITS (ITS_S $2 F$ 5'atgcgatacttggtgtgaat-3', ITS_S3R 5'-gacgcttctccagactacaat-3'). The PCR products were purified with an Exonuclease I and Shrimp Alkaline Phosphatase (Thermo Fisher Scientific, USA).

Termination reaction performed using a commercial kit Brilliant Dye Terminator v3.1 Cycle Sequencing Kit (Nimagen, Netherlands). Determination of the nucleotide sequence was performed on a genetic analyzer ABI 3500 DNA Analyzer (Applied Biosystems, USA) in a forward and reverse directions. Sequence chromatograms viewed in Sequence Scanner 1.0. Alignment of pairs of sequences conducted in the BioEdit program. The resulting consensus DNA sequences are saved in FASTA format.

To maximize the efficiency of identification and high reliability of the results, 3-4 locus genotyping was performed for all species. As a result of research, 31 consensus sequences of phylogenetically significant markers (DNA barcodes) were obtained for nine representatives of the genus Tulipa. Nucleotide sequence data were submitted in the international Genbank database with the assignment of ID numbers (GenBank: http://www.ncbi.nlm.nih.gov) (Table). Consensus sequences were compared with DNA sequences of similar species in international databases NCBI BLAST (Basic Local Alignment Search Tool) and BOLD (Barcode of Life Data Systems).

Table. Marker sequences of the studied Tulipa species in Uzbekistan submitted in GenBank

\begin{tabular}{|c|c|c|c|c|}
\hline \multicolumn{4}{|c|}{ Sequences numbers in NCBI (ID) } & \multirow{2}{*}{$\begin{array}{c}\text { Species distribution in Uzbekistan, } \\
\text { rarity status, coordinates, } \\
\text { collectors }\end{array}$} \\
\hline ITS & matK & $r b c L$ & $p s b A$ & \\
\hline \multicolumn{4}{|c|}{ Tulipa vvedenskyi Botschantz. (2019) } & \multirow{2}{*}{$\begin{array}{l}\text { Kuramin and Chatkal Ridges, } \\
\text { Tashkent region, Angren, Kattasay } \\
\text { river basin. } \\
1895 \mathrm{~m}, 41.0856 \mathrm{~N} 70.0848 \mathrm{E} \\
\text { Status 3. Rare endemic of the } \\
\text { Western Tien Shan } \\
\text { Beshko N. Yu. }\end{array}$} \\
\hline $\begin{array}{c}\text { MW854643. } \\
1 \\
389 \mathrm{bp}\end{array}$ & $\begin{array}{c}\text { MW847258 } \\
807 \text { bp }\end{array}$ & $\begin{array}{c}\text { MW847264 } \\
410 \mathrm{bp}\end{array}$ & $\begin{array}{c}\text { MW847271 } \\
480 \mathrm{bp}\end{array}$ & \\
\hline \multicolumn{4}{|c|}{ Tulipa dubia Vved. (2019) } & \multirow{2}{*}{$\begin{array}{l}\text { Tashkent region, Chimgan, Aksay } \\
\text { mountains, } \\
2011 \mathrm{~m}, 41.3048 \text { N } 70.0223 \mathrm{E}, \\
\text { Status 3. Rare endemic of the }\end{array}$} \\
\hline $\begin{array}{c}\text { MW854642. } \\
1 \\
406 \mathrm{bp}\end{array}$ & $\begin{array}{c}\text { MW847257 } \\
817 \text { bp }\end{array}$ & $\begin{array}{c}\text { MW847263 } \\
447 \mathrm{bp}\end{array}$ & $\begin{array}{c}\text { MW847270 } \\
478 \mathrm{bp}\end{array}$ & \\
\hline
\end{tabular}




\begin{tabular}{|c|c|c|c|c|}
\hline & & & & $\begin{array}{l}\text { Western Tien Shan } \\
\text { Beshko N. Yu. }\end{array}$ \\
\hline \multicolumn{4}{|c|}{ Tulipa affinis Botschantz. (2019) } & \multirow{2}{*}{$\begin{array}{l}\text { Nuratau ridge, Nurata nature reserve, } \\
\text { Majerumsay, } \\
937 \mathrm{~m}, 40.3417 \text { N } 66.4316 \mathrm{E}, \\
\text { Status 3. Rare endemic of the } \\
\text { Western Pamir-Alay } \\
\text { Beshko N. Yu. }\end{array}$} \\
\hline $\begin{array}{c}\text { MW854641. } \\
1 \\
389 \text { bp }\end{array}$ & $\begin{array}{c}\text { MW847256 } \\
718 \text { bp }\end{array}$ & $\begin{array}{c}\text { MW847262 } \\
492 \text { bp }\end{array}$ & $\begin{array}{c}\text { MW847269 } \\
449 \mathrm{bp}\end{array}$ & \\
\hline \multicolumn{4}{|c|}{ Tulipa korolkowii Regel (2019) } & \multirow{2}{*}{$\begin{array}{l}\text { Nuratau ridge, Karatash, } \\
690 \mathrm{~m}, 40.2202 \mathrm{~N} 67.2202 \mathrm{E} \\
\text { Status 3. Rare endemic of the } \\
\text { Southwestern Tien Shan and Pamir- } \\
\text { Alay with a scattered area } \\
\text { Beshko N.Yu. }\end{array}$} \\
\hline $\begin{array}{c}\text { MW854640. } \\
1 \\
376 \text { bp }\end{array}$ & & $\begin{array}{c}\text { MW847261 } \\
524 \mathrm{bp}\end{array}$ & $\begin{array}{c}\text { MW847268 } \\
445 \mathrm{bp}\end{array}$ & \\
\hline \multicolumn{4}{|c|}{ Tulipa turkestanica Regel (2013) } & \multirow{2}{*}{$\begin{array}{l}\text { Pamir-Alay, Western Tien Shan. } \\
\text { Collected in Navoi region Southern } \\
\text { slope of the Karatau ridge, near the } \\
\text { Kara-Karga pass } \\
730 \text { m, } 40.37476 \text { N } 65.50021 \text { E } \\
\text { Tojibaev K.Sh. }\end{array}$} \\
\hline $\begin{array}{c}\text { MW854645. } \\
1 \\
714 \mathrm{bp}\end{array}$ & $\begin{array}{c}\text { MW847260 } \\
876 \text { bp }\end{array}$ & $\begin{array}{c}\text { MW847266 } \\
918 \text { bp }\end{array}$ & & \\
\hline \multicolumn{4}{|c|}{ Tulipa mogoltavica Popov et Vved. (1954) } & \multirow{2}{*}{$\begin{array}{l}\text { Western Tien Shan. Collected in } \\
\text { Kuramin Ridge. Altyn-topkan } \\
\text { mountains. Altyn-tapkan region in } \\
\text { the juniper forest. } \\
840 \mathrm{~m}, 40.6500 \mathrm{~N} 69.6333 \mathrm{E} \text {, } \\
\text { Vernik R. }\end{array}$} \\
\hline $\begin{array}{c}\text { MW854644. } \\
1 \\
710 \mathrm{bp}\end{array}$ & $\begin{array}{c}\text { MW847259 } \\
878 \text { bp }\end{array}$ & $\begin{array}{c}\text { MW847265 } \\
926 \text { bp }\end{array}$ & & \\
\hline \multicolumn{4}{|c|}{ Tulipa bifloriformis Vved (2019) } & \multirow{2}{*}{$\begin{array}{l}\text { Western Tien Shan. Collected in } \\
\text { Tashkent region, Chimgan, Aksay } \\
\text { mountains. } \\
1907 \text { m, } 41.3051 \text { N } 70.0205 \text { E } \\
\text { Beshko N.Yu. }\end{array}$} \\
\hline & $\begin{array}{c}\text { MW847255 } \\
816 \text { bp }\end{array}$ & $\begin{array}{c}\text { MW847267 } \\
495 \mathrm{bp}\end{array}$ & & \\
\hline \multicolumn{4}{|c|}{ Tulipa ferganica Vved. (2015) } & \multirow{2}{*}{$\begin{array}{l}\text { Chatkal, Fergana and Alay ranges } \\
\text { (Namangan, Andijan and Fergana } \\
\text { regions) } \\
41.25999 \text { N } 71.89778 \text { E } \\
\text { Status 2. Rare endemic of the } \\
\text { Fergana Valley. } \\
\text { Tojibaev K.Sh. }\end{array}$} \\
\hline $\begin{array}{c}\text { MW826216. } \\
1 \\
715 \text { bp }\end{array}$ & $\begin{array}{c}\text { MW828755 } \\
755 \text { bp }\end{array}$ & $\begin{array}{c}\text { MW828759 } \\
928 \text { bp }\end{array}$ & $\begin{array}{c}\text { MW828757 } \\
817 \mathrm{bp} \\
\text { (trnL) }\end{array}$ & \\
\hline \multicolumn{4}{|c|}{ Tulipa intermedia Tojibaev et J.J. de Groot (2013) } & \multirow[b]{2}{*}{$\begin{array}{l}\text { Namangan region (Chust and Pap } \\
\text { regions): Kuramin ridge } \\
941 \mathrm{~m}, 40.94155 \mathrm{~N} 70.86736 \mathrm{E} \\
\text { Status 2. A rare species of adyr in } \\
\text { the northern part of the Fergana } \\
\text { Valley } \\
\text { Tojibaev K.Sh. }\end{array}$} \\
\hline $\begin{array}{c}\text { MW826215. } \\
1\end{array}$ & MW828754 & MW828758 & $\begin{array}{l}800 \mathrm{bp} \\
(\operatorname{trnL})\end{array}$ & \\
\hline
\end{tabular}

Good reproducibility of amplification results was demonstrated for all markers. So, DNA sequences were compared to known and well characterized sequence in the BLAST database. The similarity with sequences was at least $98 \%$. Marker sequences for the species Tulipa mogoltavica, Tulipa ferganica, Tulipa intermedia, Tulipa affinis, Tulipa dubia are presented to the database for the first time.

The choose of one or another molecular marker, the variability of which is a basis for the work, is one of the important tasks, since the random of evolutionary changes in a specific DNA segment determines the level phylogenetic resolution and may be different in different organisms. 
Many researchers have noted the high efficiency of the ITS nuclear region as a DNA barcode in both cases, using independently (up to $92.7 \%$ of all studied species) and in combination with chloroplast markers.

Nuclear DNA regions are also under interest due to a high variability and a high discrimination rate compared to mitochondrial and chloroplast genes. Therefore, the second internal transcribed spacer (ITS) of nuclear ribosomal DNA represents the most suitable region for molecular genetic studies in plant taxonomy at the "genus, species, subspecies" taxon levels, for DNA barcoding applications. As a rule, the lengths of the combined internal transcribed spacer ITS region (ITS1 is located between 18S and 5.8S rRNA genes, ITS2 is between $5.8 \mathrm{~S}$ and 28S) are given in the NCBI databases.

A phylogenetic analysis of 8 tulip species was performed based on the obtained nucleotide sequences of the ITS nuclear region. A fragments of target marker ranged from $\sim 400$ to $\sim 700$ bp were obtained by amplification of plant DNA. Seven sequences of the ITS region used for a phylogenetic dendrogram construction were download from the GenBank database. The region for comparing sized 329 b.p.

The model choose was estimate using the jModelTest 2.1.10 program [10]. The nucleotide sequences alignment was performed using the ClustalW algorithm [11].

The results of hierarchical clustering are presented by a constructed dendrogram obtained by the Maximum Likelihood (ML) method in the MEGA5 program; the reliability assess of the resulting phylogenetic tree topology was obtained with Bootstrap analysis (1000 replicates). The resulting graphic image was visualized using the FigTree v1.4.0 program.

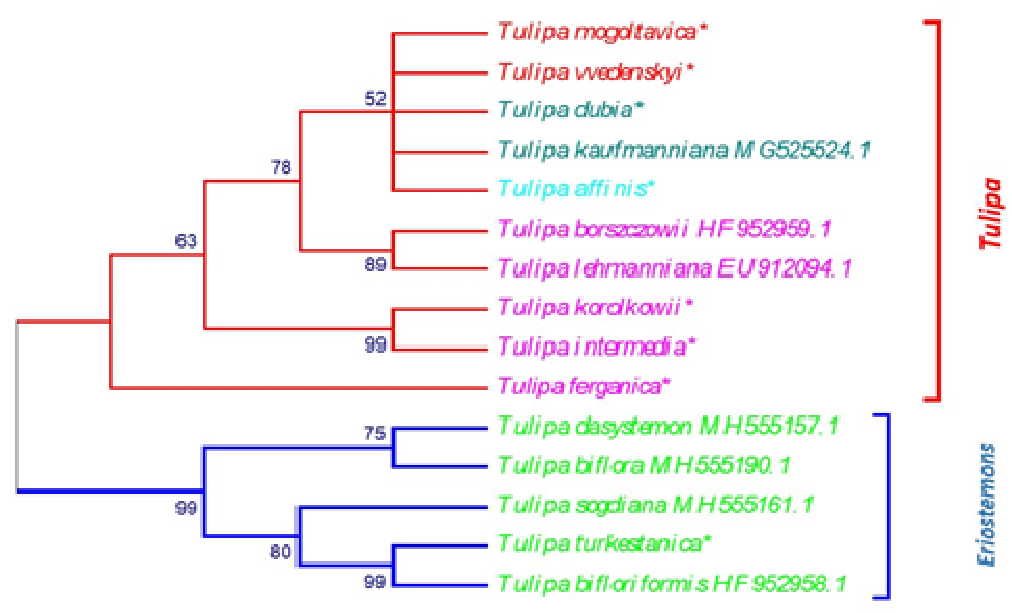

Fig. Hierarchical clustering of 15 taxa of the genus Tulipa, constructed by sequence comparison of the ITS region (Bootstrap support values are indicated)

The phylogenetic tree constructed using the ITS region based on the ML algorithm (congruent with NJ) shows a clear division of the genus into two main clades by subgenera, with a high Bootstrap value: Tulipa and Eriostemons.

Subgenus Tulipa formed groups belonging to four sections

1) Vinistriatae (Raamsd.) Zonn. (T. mogoltavica, T. vvedenskyi);

2) Spiranthera Vved. ex Zonn. et Veldk. (T. kaufmanniana, T. dubia);

3) Lanatae (Raamsd.) Zonn. (T. affinis);

4) Kolpakovskiana Raamsd. ex Zonn. et Veldk. (T. ferganica, T. korolkowii, T. borszczowii, T. lehmanniana, T. intermedia). 
The subgenus Eriostemons grouped a species of section Biflores A. D. Hall ex Zonn. et Veldk.: T. turkestanica, T. biflora, T. bifloriformis, T. dasystemon, T. sogdiana into a separate clade.

Thus, hierarchical clustering showed results consistent with the classical classification of the genus Tulipa L., proving the taxonomic position of taxa according to their morphological characters [8]. This division also coincides with the molecular phylogenetic studies of genus Tulipa L. by other authors [5, 6, 12].

Thus, the results obtained in this research make possible to compile a DNA barcode national reference library for rare and endangered plant species growing on the territory of Uzbekistan. This work demonstrates the effectiveness of using DNA barcoding as a tool for the diversity assessing of rare plant species.

The work was carried out within the framework of the project: MRB-AN-2019-30 "Genetic inventory of rare and endangered plant species in Belarus and Uzbekistan using DNA barcoding technology."

\section{References}

1. W. Li, K. Sh. Tojibaev, H. Hisoriev, Kh. F. Shomurodov, M. Luo, Y. Feng, K. Ma, Global Ecology and Conservation 24 (2020)

2. Y. Zhang, D. Zhang, W. Li, Y. Li, C. Zhang, K. Guan, B. Pan, Regional Sustainability 1 (1) (2020)

3. K. Sh. Tojibaev, N. Yu. Beshko, V. A. Popov, C. G. Jang, K. S. Chang, Botanical Geography of Uzbekistan (GeoBook Publishing Co. K.Sh., 2017).

4. L. Peruzzi, Plant Biosystems 150 (6) (2016)

5. B. Zonneveld, Plant Syst Evol., 281 (2009)

6. M. Christenhusz, R. Govaerts, J. David, T. Hall, K. Borland, P. Roberts, A. Tuomisto, S. Buerki, M. Chase, M. Fay, Botanical Journal of the Linnean Society, 172 (2013).

7. D. Everett, The genus Tulipa: Tulips of the world (Kew, Kew Publishing Royal Botanic Gardens, 2013).

8. K. Tojibaev, N. Beshko, Nordic Journal of Botany 33, 3 (2015)

9. The Red book of Uzbekistan. Plants (Tashkent, Chinor ENK, 2019)

10. D. Darriba, G. Taboada, R. Doallo, D. Posada, Nature Methods 9 (2012)

11. J. Thompson, T. Gibson, D. Higgins, Current Protocols in Bioinformatics (2002)

12. M. Türktas, Ö. Metin, B. Bastug, F. Ertugrul, Y. Saraç, E. Kaya, Botanical Journal of the Linnean Society 172 (2013) 